\title{
Enzyme linked immunosorbent assay (ELISA) and immunoprecipitation studies on anti-goblet cell antibody using a mucin producing cell line in patients with inflammatory bowel disease
}

\author{
T Hibi, M Ohara, K Kobayashi, W R Brown, K Toda, H Takaishi, Y Hosoda, A Hayashi, \\ Y Iwao, M Watanabe, S Aiso, Y Kawai, M Tsuchiya
}

\begin{abstract}
Circulating anti-goblet cell antibody and its corresponding antigen in patients with inflammatory bowel disease were investigated. Antigoblet cell antibody in the serum was examined by immunocytochemistry and enzyme linked immunosorbent assay (ELISA), using a colonic cancer cell line, HT29-18- $\mathbf{N}_{2}$, which differentiates into intestinal goblet cells. The frequencies of anti-goblet cell antibody detected by immunocytochemistry were 14 in 48 patients with ulcerative colitis $(29 \%)$ and five in 15 patients with Crohn's disease (33\%). By ELISA, the frequencies of anti-goblet cell antibody were $38 \%$ in ulcerative colitis and $33 \%$ in Crohn's disease. This antibody did not relate directly to anti-neutrophil cytoplasmic antibodies (ANCA), although the serum samples positive for anti-goblet cell antibody were commonly positive for ANCA in ulcerative colitis. Immunoprecipitation and SDS polyacrylamide gel electrophoresis (PAGE) study showed that the antibody in the ELISA positive serum samples recognised a $>200 \mathrm{kD}$ goblet cell antigen, which remained unchanged after reduction, indicating that it consists of single chain polypeptides. These results suggest that there is a subgroup of inflammatory bowel disease that has circulating anti-goblet cell antibody reactive with $\mathrm{a}>200 \mathrm{kD}$ antigen. The antibody detected by newly established ELISA will be a disease marker for this group and the identification of the corresponding antigens may be important for the understanding of the underlying immune abnormalities. (Gut 1994; 35: 224-230)
\end{abstract}

Accumulative evidence suggests that ulcerative colitis is one of the autoimmune diseases in which various autoantibodies are often found. ${ }^{1-3}$ In ulcerative colitis, two kinds of autoantibodies to colonic epithelial cells have been proposed. One is the classic antibody that reacts with phenol water extracts of fetal colonic tissue and mucopolysaccharide in colonic goblet cells. ${ }^{1}$ Since this anti-goblet cell (anti-mucin) autoantibody was proposed by Broberger and Perlmann in $1959,1^{\prime}$ numerous studies on this kind of antibody have been performed by various investigators. ${ }^{48}$ Nevertheless, any simple assay for this antibody has not been developed and the characteristics of the corresponding antigens remain unclear. The other antibody is anticolonic epithelial cell antibody, which mainly reacts with the membrane of the surface epithelial cells in the colon and mediates specific cytotoxicity to colonic epithelial cells. ${ }^{9-11}$ Except for a $40 \mathrm{kD}$ colitis colon associated antigen described by Das et al, ${ }^{12-14}$ no other colon specific antigens have been clarified yet. We have reported the high incidence of anti-colon antibody, which reacts with the surface of isolated rat colonic epithelial cells and the presence of antibody dependent cell mediated cytotoxicity activity in the serum samples from patients with ulcerative colitis. ${ }^{10}$

The other autoantibodies, anti-neutrophil cytoplasmic antibodies (ANCA), have been recently found in inflammatory bowel disease. ${ }^{15}$ ANCA were present in most patients with ulcerative colitis and a small subset of patients with Crohn's disease.

The significance of these antibodies in the pathogenesis of ulcerative colitis is still uncertain, and some investigators insist that the production of circulating autoantibodies in inflammatory bowel disease is an epiphenomenon. Characterisation of the antigens recognised by the autoantibodies is essential for determination of the pathogenetic importance of the antibodies. In addition, the identification of the antigens may allow us to establish more precise diagnostic methods for this disease. Extraction of the colon specific antigens, however, from human colonic tissue is often difficult because colonic tissue contains many kinds of other substances. Thus, cell lines containing the antigens may be more useful. A human colonic cancer cell line, HT28-18- $\mathrm{N}_{2},{ }^{16}$ which differentiates into goblet cells producing mucin in confluent cell culture, is a good source of the antigens recognised by an anti-goblet cell antibody.

There have been no studies on the characterisation of the antigens recognised by anti-goblet cell antibody and the relation between ANCA and anti-goblet cell antibody. In this study, we focused on anti-goblet cell antibody and compared this antibody with the other autoantibodies, ANCA. Using mucin producing colonic epithelial cells (HT29-18- $\mathrm{N}_{2}$ ), we developed an improved method for detecting serum antigoblet cell antibody and characterised the antigen detected by this antibody in inflammatory bowel disease.

\section{Patients and methods}

SERUM SAMPLES

Ulcerative colitis or Crohn's disease was diag- 
nosed on the basis of typical clinical, radiographic, and pathological features. Serum samples were obtained from 48 patients with ulcerative colitis, 15 patients with Crohn's disease, five patients with colon cancer, seven patients with colon polyp, six patients with colon diverticulitis, 12 patients with infectious colitis (four Campylobacter colitis, two colon tuberculosis, and six amoebic colitis), five patients with rheumatoid arthritis, and two patients with systemic lupus erythematosus. The mean age of the patients with ulcerative colitis was 32 years (range 17-52). Thirty three of the patients had relapsing type and 15 patients had chronic continuous type of disease. Nineteen patients were in active stage and 29 patients in inactive stage. The disease activity was calculated according to a previous report ${ }^{17}$ in which the scores were made by frequencies of bowel movement, blood in stool, body temperature, abdominal pain, and pulse rate. The scores ranged from 0 to 8 . The patients with scores more than three were regarded as in active stage. The mean age of the patients with Crohn's disease was 29 years (range 15-36). All of them had active disease (Crohn's disease activity indices of $>150$ ) when the serum samples were obtained. Seven patients had colitis disease type and eight ileocolitis type. None of the patients received corticosteroids. Control serum samples were obtained from 35 healthy hospital workers whose sex and age distribution was comparable with that of the patient group. Serum samples were stored at $-80^{\circ} \mathrm{C}$ without preservatives and centrifuged at $105000 \mathrm{~g}$ for 90 minutes before use.

IMMUNOCYTOCHEMISTRY FOR THE DETECTION OF CIRCULATING ANTI-GOBLET CELL ANTIBODY

Human colonic cancer cell line, HT29, and its subclone, HT29-18- $\mathrm{N}_{2}$, were cultured in 8 well Lab-Tec chambers (Nunc Inc, Naperville, IL, USA) on slide glass. At confluence, cells were fixed in ethanol solution for one second. After being washed, the slides were incubated with phosphate buffered saline containing $10 \%$ rabbit serum and then with 1:50 diluted serum in a moist chamber at room temperature for 30 minutes. The slides were washed three times by immersion in excess phosphate buffered saline. After being washed, the slides were stained by the addition of fluorescein isothiocyanate (FITC) conjugated rabbit anti-human IgG $\mathrm{F}\left(\mathrm{ab}^{\prime}\right)_{2}$ (Dako, Santa Barbara, CA, USA), diluted 1:25 with phosphate buffered saline, and then studied under fluorescent microscope. The slides were coded and read in a blinded manner.

IMMUNOHISTOCHEMISTRY FOR THE DETECTION OF ANTI-GOBLET CELL ANTIBODY

Colonic biopsy specimens were obtained endoscopically or at colectomy. Tissue specimens were embedded in an ornithine carbamoyltransferase compound and frozen. Sections $6 \mu \mathrm{m}$ thick were fixed with ethanol at $4^{\circ} \mathrm{C}$ for 10 minutes. The preparations were incubated with patient or control serum (diluted at 1:50 with phosphate buffered saline containing $10 \%$ rabbit serum) overnight in a moist chamber and washed in phosphate buffered saline. They were then incubated with peroxidase labelled rabbit antihuman IgG F $\left(\mathrm{ab}^{\prime}\right)_{2}$ (Dako, Santa Barbara, CA, USA) for 30 minutes. After further washing, peroxidase activity was developed with diaminobenzidine and hydrogen peroxide, and the slides were examined by light microscopy in a blinded manner.

\section{PREPARATION OF HORSERADISH PEROXIDASE} LABELLED $\mathrm{F}\left(\mathrm{ab}^{\prime}\right)_{2}$ OF POSITIVE AND NEGATIVE SERUM SAMPLES

One strongly positive serum from a patient with ulcerative colitis and a negative serum were separately precipitated in $50 \%$ ammonium sulfate and purified by adsorption to a protein Asepharose CL-4B column and elution with $0 \cdot 1 \mathrm{M}$ acetic acid. Immunoglobulins were digested by reaction with pepsiri and $(1: 50 \mathrm{wt} / \mathrm{wt}$ pepsin: protein) in $0.05 \mathrm{M}$ acetate buffer, $\mathrm{pH} \mathrm{4.5}$, and chromatography on sephacryl S-200. F $\left(\mathrm{ab}^{\prime}\right)_{2}$ was conjugated to horseradish peroxidase type 6 as described. ${ }^{18}$ Direct immunocytochemistry against HT29-18- $\mathrm{N}_{2}$ and immunohistochemistry against colonic biopsy specimens using HRP$\mathrm{F}\left(\mathrm{ab}^{\prime}\right)_{2}$ was performed.

ELISA FOR THE DETECTION OF ANTI-GOBLET CELL ANTIBODY

A mucin rich fraction was obtained from a confluent culture of HT29-18- $\mathrm{N}_{2}$ cells. Cells that differentiated into mucin producing cells in two weeks after they were confluent in culture, were sonicated and centrifuged at $105000 \mathrm{~g}$ for 60 minutes to remove nuclei. The supernatant was dialysed against deionised water and then used as the solid phase antigen for ELISA after the protein concentration was measured and $\mathrm{pH}$ was fixed to $7 \cdot 2$. EIA plates (Flow Laboratories, McLean, Virginia, USA) were coated with this mucin rich fraction at $0.1 \mu \mathrm{g}$ protein $/ \mathrm{ml}$ overnight at $4^{\circ} \mathrm{C}$. After being washed, the plates were incubated with $200 \mu \mathrm{l}$ of blocking buffer (1\% bovine serum albumin in $0.1 \mathrm{M}$ sodium bicarbonate, $\mathrm{pH} 8 \cdot 2$ ) at $22^{\circ} \mathrm{C}$ for four to six hours. The plates were washed three times with phosphate buffered saline, then incubated with $200 \mu$ l of diluted serum (1:200 dilution with phosphate buffered saline adding $10 \%$ goat serum) at $37^{\circ} \mathrm{C}$ for one hour. Serum was discarded and the plates were washed three times with phosphate buffered saline. The plates were then incubated with $200 \mu \mathrm{l}$ of 1:2500 dilution of goat anti-human IgG conjugated to alkaline phosphatase at $37^{\circ} \mathrm{C}$ for one hour. After being washed, the plates were incubated with $200 \mu \mathrm{l}$ of $0.5 \mathrm{mM}$ p-nitrophenylphosphate. The optical density was read at $409 \mathrm{~nm}$ with TOYO EYE-III ELISA reader (TOYO, Tokyo, Japan). Wells with optical densities greater than two standard deviations above the mean of the healthy control serum samples were scored as positive for anti-goblet cell antibody activity. For the absorption study with neutrophils, the serum samples were incubated with $10^{8}$ neutrophils at $37^{\circ} \mathrm{C}$ for three hours and then tested for anti-goblet cell antibody. 
ELISA FOR THE DETECTION OF ANTI-NEUTROPHIL CYTOPLASMIC ANTIBODIES (ANCA)

The fixed neutrophil ELISA reported by Duerr et al ${ }^{19}$ was applied to detect ANCA. Briefly, wells of microtitre plates were coated with a monolayer of isolated neutrophils by the addition of $100 \mu \mathrm{l} /$ well of Hank's balanced buffered salt solution that contained 250000 neutrophils isolated from peripheral blood of healthy controls. The plates were centrifuged at $1000 \mathrm{rpm}$ for five minutes and dried. The cells were fixed with $100 \%$ methanol for 10 minutes. After being washed, the plates were incubated with $150 \mu$ l of blocking buffer $(0.25 \%$ bovine serum albumin in phosphate buffered saline) at $22^{\circ} \mathrm{C}$ for four to six hours. The plates were washed three times with phosphate buffered saline, then incubated with $100 \mu$ l of diluted serum (1:100 dilution with phosphate buffered saline containing $0.25 \%$ bovine serum albumin) at room temperature for one hour. Serum was discarded and the plates were washed three times with $0.05 \%$ TWEEN 20 in phosphate buffered saline. The plates were then incubated with $100 \mu \mathrm{l}$ of 1:2500 dilution of goat anti-human IgG conjugated to alkaline phosphatase at $37^{\circ} \mathrm{C}$ for one hour. After being washed three times with $0.05 \%$ TWEEN 20 in phosphate buffered saline and four times with $0.05 \mathrm{~mol} / 1$ TRIS base in $0.9 \mathrm{~mol} / 1 \mathrm{NaCl}, \mathrm{pH} 7.5$, the plates were incubated with $100 \mu \mathrm{l}$ of $0.5 \mathrm{mM}$ p-nitrophenyl-phosphate. The optical density was read at $409 \mathrm{~nm}$ with TOYO EYT-III ELISA reader (TOYO, Tokyo, Japan). Wells with optical densities greater than two standard deviations above the mean of the healthy control serum samples were scored as positive for ANCA activity.

Figure 1:

Immunocytochemical staining of postconfluent HT29-18- $N_{2}$ cells by serum from a healthy control (left) and $a$ patient with ulcerative colitis (right) (original magnification $\times 400$ )

Mucin producing cells that were shown by periodic acid Schiff staining, were immunofluorescently stained by serum from a patient with ulcerative colitis.
Immunocytochemistry for anti-goblet cell antibody

\begin{tabular}{llll}
\hline & $(-)$ & $(+)$ & $(++)$ \\
\hline Healthy control $(n=35)$ & $34 / 35$ & $\frac{1 / 35 \quad 0 / 35}{3}$ \\
Ulcerative colitis $(n=48)$ & $34 / 48$ & $\frac{9 / 48 \quad 5 / 48}{33 \%}$ \\
Crohn's disease $(n=15)$ & $10 / 15$ & $\frac{5 / 15 \quad 0 / 15}{29 \%}$ \\
\hline
\end{tabular}

$(-)$ : negative, $(+)$ : positive, $(++)$ : strongly positive.
IMMUNOCYTOCHEMISTRY FOR ANCA

Neutrophils were fixed in $100 \%$ methanol at room temperature for 10 minutes on glass slides. After being washed, the slides were incubated with phosphate buffered saline containing $10 \%$ rabbit serum and then with 1:20 diluted serum in a moist chamber at room temperature for 30 minutes. After being washed with phosphate buffered saline, the slides were stained by the addition of fluorescein isothiocyanate conjugated rabbit anti-human IgG $\mathrm{F}\left(\mathrm{ab}^{\prime}\right)_{2}$ (Dako, Santa Barbara, CA, USA) diluted 1:25 with phosphate buffered saline and then studied under fluorescent microscope. The slides were coded and read in a blinded manner.

\section{SEROLOGICAL HLA TYPING}

Typing for HLA-DR was performed by the standard NIH complement dependent microlymphocyte toxicity assay.

IMMUNOPRECIPITATION AND SDS-PAGE STUDY FOR THE ANTIGEN RECOGNISED BY ANTI-GOBLET CELL ANTIBODY

HT29-18- $\mathrm{N}_{2}$ cells were cultured in a $25 \mathrm{~cm}^{2}$ flask at about $75 \%$ confluence using complete medium without methionine. ${ }^{35} \mathrm{~S}$-methionine $(0.5 \mathrm{mCi})$ was added to the medium overnight. After cells were washed once with phosphate buffered saline, lysis buffer was added. Cells were scraped from the plate with a rubber policeman. The lysis buffer and cell debris were transferred to a tube and spun for 15 minutes at $13000 \mathrm{~g}$ at $4^{\circ} \mathrm{C}$. For the antibody-antigen reaction, IgG fraction of serum was added to the lysate. After overnight incubation in a $4^{\circ} \mathrm{C}$ cold room with rocking, protein $\mathrm{A}$ shepharose $4 \mathrm{~B}$ beads were added to the same tube and incubated for 30 minutes at $4^{\circ} \mathrm{C}$ with rocking. For SDS-PAGE, the sample buffer was added to immune complexes and heated to $56^{\circ} \mathrm{C}$ for 20 minutes. The extracted proteins were then separated by $7 \cdot 5 \%$ SDSPAGE and finally shown by fluorography.

\section{Results}

ANTIBODY AGAINST HT29-18- $\mathrm{N}_{2}$ CELLS DETECTED BY IMMUNOCYTOCHEMISTRY IS EQUIVALENT TO ANTI-GOBLET CELL ANTIBODY

Immunofluorescent study showed that some populations of HT29-18- $\mathrm{N}_{2}$ cells in a confluent culture were stained by serum samples from 14 of $48(29 \%)$ patients with ulcerative colitis (Table, Fig 1). Periodic acid Schiff staining showed that the cell populations stained clearly by serum samples from patients with ulcerative colitis corresponded to mucin containing cells. When parent cell line HT-29 were used, few cells were stained by the positive serum samples even in a confluent culture. In Crohn's disease, five of $15(33 \%)$ samples stained mucin producing cells positively. Among 35 samples from healthy controls, only one serum was weakly positive for antibody against HT29-18- $\mathrm{N}_{2}$ cells and the other 34 samples were negative. Serum samples that were positive by immunocytochemistry were tested for staining of human colonic tissue. By 


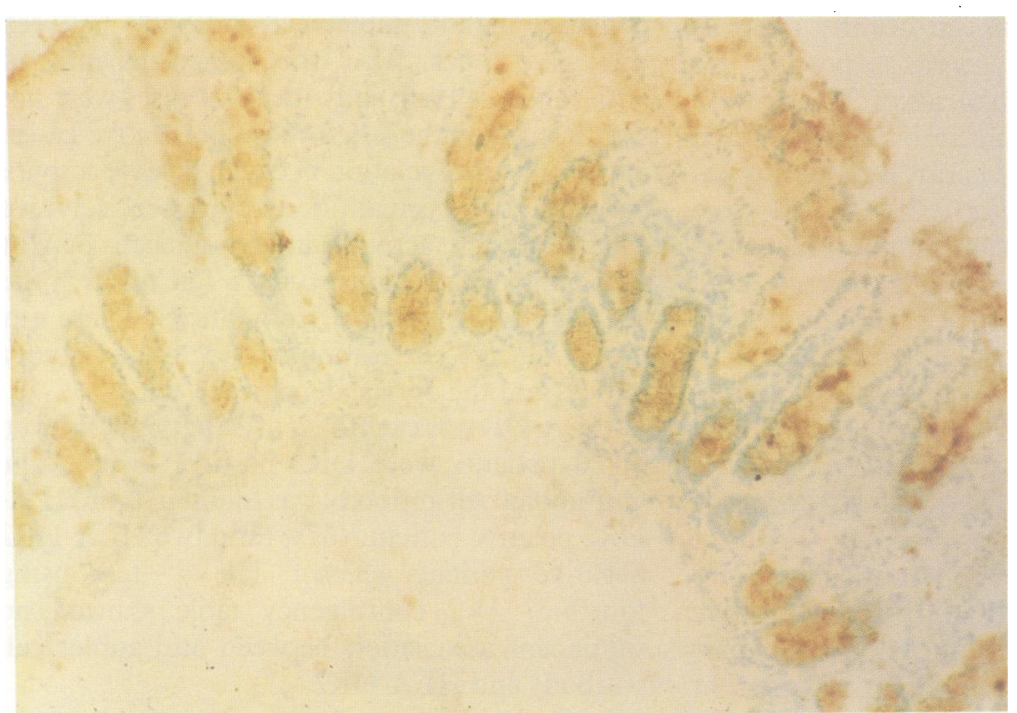

Figure 2:

Immunohistochemical staining of human colonic tissue by serum from a patient with ulcerative colitis (original magnification $\times 100)$. Goblet cells were positively stained by the serum.

Figure 3: Anti-goblet cell antibody detected by ELISA in various populations of patients. Anti-goblet cell antibody was present in 18 of 48 patients with ulcerative colitis and five of 15 patients with Crohn's disease. No positive serum samples were found, however, in the other colonic diseases and

autoimmune diseases. $R A=$ rheumatoid arthritis, SLE= systemic lupus

erythematosus.

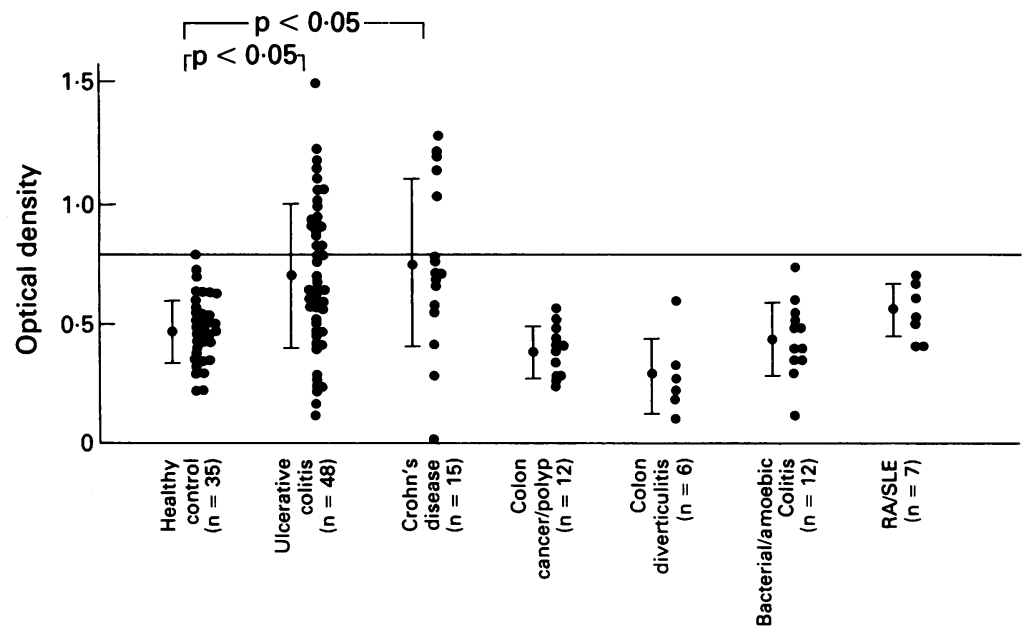
in immunohistochemistry. In contrast, all of the samples positive against $\mathrm{HT} 29-18-\mathrm{N}_{2}$ cells reacted with goblet cells in colonic mucosa (Fig 2). HRP-F $\left(\mathrm{ab}^{\prime}\right)_{2}$ of the positive serum had the same staining intensity as did the serum by the indirect method, showing that the staining was not due to the binding of IgG by its Fc region.

\section{ANTIBODY DETECTED BY ELISA IS SIMILAR TO THAT} DETECTED BY IMMUNOCYTOCHEMISTRY

The serum from a patient with ulcerative colitis with high titre for anti-goblet cell antibody ascertained by immunohistochemistry with human colonic tissue and immunocytochemistry with HT29-18- $\mathrm{N}_{2}$ cells, was tested by ELISA in serial dilution. In comparison with normal serum, the optical densities of the patient's serum were high at any dilution tested. Absorption studies were done on two samples with high activity for anti-goblet cell antibody. After the samples were incubated with mucin rich fraction from HT29-18- $\mathrm{N}_{2}$ cells for three hours at room temperature, the optical densities of the samples were reduced to values similar to those of healthy control samples.

Figure 3 shows the frequencies of anti-goblet cell antibody. When the optical densities greater than two standard deviations above the mean of the healthy controls $(0.476+2 \times 0.137)$ were scored as positive for anti-goblet cell antibody activity, the frequencies of anti-goblet cell antibody were $38 \%$ ( 18 of 48 patients) in ulcerative colitis. Among 18 positive serum samples in ELISA, 14 were positive and four were negative in immunocytochemistry. Five of 15 samples (33\%) from Crohn's disease that were positive in immunocytochemistry, were also positive in ELISA. When compared with healthy controls, the optical densities mean (SD) in ulcerative colitis $(0.698(0.268))$ and in Crohn's disease $(0.746(0.363))$ were significantly high. No serum samples from patients with colon cancer, colon polyp or colon diverticulitis, however, were positive in ELISA. The optical densities of the samples from 12 patients with bacterial/ amoebic colitis were $0.434(0 \cdot 156)$ and those in seven patients with rheumatoid arthritis or systemic lupus erythematosus were 0.536 $(0 \cdot 110)$. Those were not significantly different from the optical densities of healthy controls' serum samples.

\section{LEVELS OF ANTI-GOBLET CELL ANTIBODY DID NOT CORRELATE WITH THOSE OF ANCA IN ELISA}

ANCA were first examined by immunocytochemistry. The serum samples from patients with ulcerative colitis that could stain perinuclear cytoplasm of the neutrophils intensely, were used as positive control for ELISA. Figure 4 shows the frequencies of ANCA. When the optical densities greater than two standard devia-

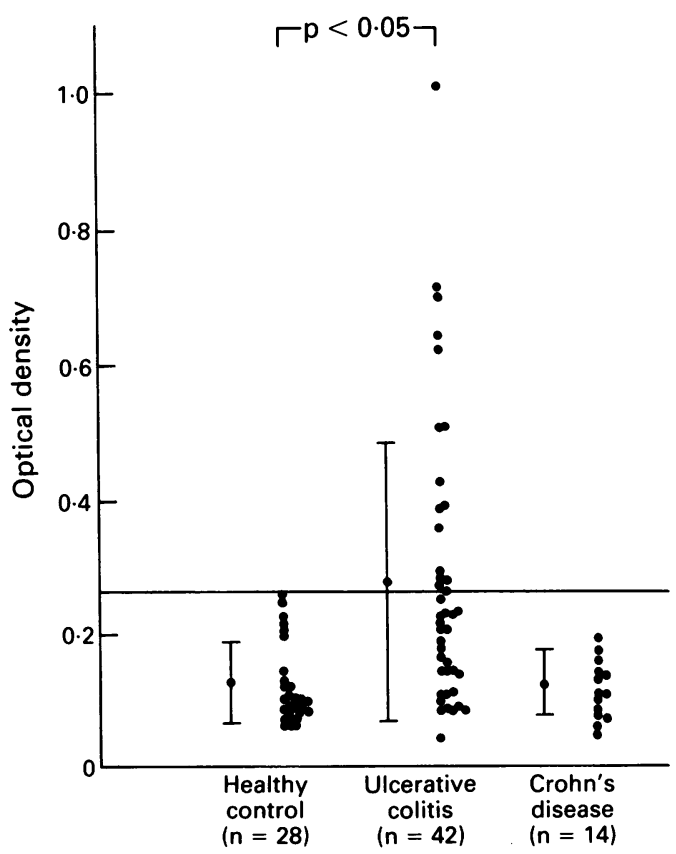

Figure 4: Anti-neutrophil cytoplasmic antibody detected by ELISA in ulcerative colitis and Crohn's disease. Antineutrophil cytoplasmic antibody was positive in 15 of 42 patients with ulcerative colitis. There was no positive serum in Crohn's disease. 
tions above the mean of the healthy controls $(0 \cdot 120+2 \times 0 \cdot 062)$ were scored as positive for ANCA activity, the frequencies of ANCA were $35 \%$ in 42 patients with ulcerative colitis. When compared with healthy controls, the optical densities in ulcerative colitis $(0 \cdot 281(0 \cdot 210))$ were significantly high. No serum samples, however, from 14 patients with Crohn's disease were positive. The optical densities for anti-goblet cell antibody were compared with those for ANCA in 37 patients with ulcerative colitis. The correlation coefficient was $0 \cdot 274(p=0 \cdot 1029)$. There was no significant correlation between the levels of these two antibodies. The $\chi^{2}$ test, however, using fourfold, $2 \times 2$ contingency table (eight of 37 patients positive for both antibodies, five positive for anti-goblet cell antibody, six positive for ANCA, and 18 negative for both antibodies) showed that significant association was present between these two antibodies $\left(\chi^{2}=4 \cdot 79\right.$, $\mathrm{p}<0.05)$. Three samples positive for both antibodies and three samples for anti-goblet cell antibody were incubated with neutrophils and then tested for anti-goblet cell antibody. There were no significant difference in optical densities for anti-goblet cell antibody between the treated and the untreated samples.

\section{SENSITIVITY OF ANTI-GOBLET CELL ANTIBODY DOES NOT RELATE DIRECTLY TO CLINICAL FEATURES OR HLA-DR}

The relation between anti-goblet cell antibody activity and clinical features was examined. Seven of 15 patients (47\%) with chronic continuous type disease had anti-goblet cell antibody in ELISA, while nine of 33 patients (28\%) with relapsing type were positive. Nevertheless, there was no significant difference in optical

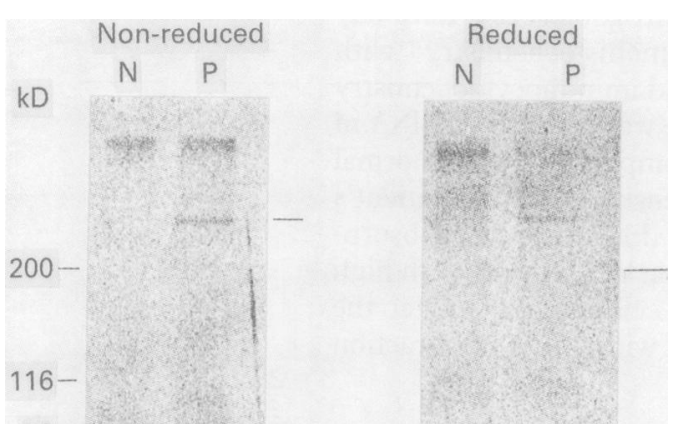

Figure 5: Autoradiograph of material immunoprecipitated from ${ }^{3} S$-methioninelabelled HT29-18- $\mathrm{N}_{2}$ cells by the serum samples from an ulcerative colitis patient containing anti-goblet cell antibody (as detected by ELISA) and from a normal control. A specific band is present at $>200 \mathrm{kD}$ in material precipitated by the patient's $(P)$ serum but not by normal control $(N)$ serum. densities of anti-goblet cell antibody between these two types. Also, the optical densities of anti-goblet cell antibody in active cases were not significantly higher than those in inactive cases. To discover the relation between disease activity and anti-goblet cell antibody more precisely, we calculated the activity index in each patient according to a previous study. ${ }^{17}$ The mean of the activity indices was $2 \cdot 8$ (from 0 to 8 ). There was no significant correlation between the activity indices and the optical densities.

HLA-DR was examined in 20 patients. Eleven of 20 patients were DR2 positive (55\%). The anti-goblet cell antibody was found in four HLADR2 positive patients $(67 \%)$ and two HLA-DR2 negative patients $(33 \%)$. The $\chi^{2}$ test using fourfold, $2 \times 2$ contingency table showed no significant association between anti-goblet cell antibody and HLA-DR2.

In Crohn's disease, four serum samples from patients with colitis and one sample from a patient with ileocolitis were positive. Among 10 negative samples, three were from patients with colitis and seven were from patients with ileocolitis. There was no significant difference, however, in the optical densities between colitis type and ileocolitis type.

ANTI-GOBLET CELL ANTIBODY RECOGNISES THE ANTIGEN EXTRACTED FROM HT29-18- $\mathrm{N}_{2}$ CELLS WITH MOLECULAR WEIGHT OF MORE THAN $200 \mathrm{kD}$ Immunoprecipitation and SDS-PAGE study showed that anti-goblet cell antibody positive serum reacted with the antigen extracted from HT29-18- $\mathrm{N}_{2}$ cells, whereas antibody negative serum from healthy control did not. The molecular weight of that antigen seemed to be more than $200 \mathrm{kD}$ (Fig 5). After the extract from HT29-18- $\mathrm{N}_{2}$ cells was reduced, the positive serum reacted with it at the same position as with the non-reduced extract. All of the antibody positive serum samples from 14 patients with ulcerative colitis and five patients with Crohn's disease reacted with the $>200 \mathrm{kD}$ antigen, whereas the samples from five healthy controls and the negative samples from six patients with ulcerative colitis did not react (Fig 6).

\section{Discussion}

To detect anti-colon antibodies in the serum samples from patients with ulcerative colitis, various kinds of techniques have been applied. Immunofluorescent or immunohistochemical studies using colonic tissue are often used. ${ }^{6-8}$ Interpretation of the positive or negative staining is sometimes difficult, however, because of the background staining or non-specific staining in poorly prepared tissue sections. In our immunohistochemical study, there were also some questionable cases in which goblet cells were weakly stained. Therefore, we evaluated an immunocytochemical method, using a colon cancer cell line, HT29-18- $\mathrm{N}_{2}$, which differentiates into mucin producing goblet cells in confluent culture. ${ }^{16}$ In this method, identification of positive or negative staining was easy, as only mucin producing cells were stained clearly. We tried next to establish an ELISA for the detection 


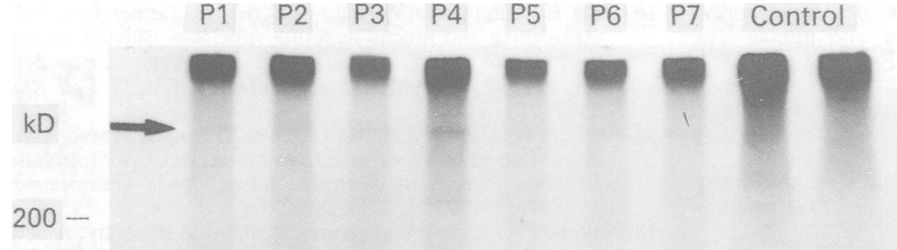

$94-$

Figure 6: SDS-PAGE analysis of material precipitated from HT29-18$\mathrm{N}_{2}$ cells by serum sample from five patients with ulcerative colitis $(P 1-P 5)$ and two with Crohn's disease (P6, P7). A specific band was present at $>200 \mathrm{kD}$, whereas no such material was precipitated by samples from two healthy control subjects. Most of the radiolabel at the top of the gel was non-specific high molecule complexes or nonspecific agglutinated substances that bound to protein $A$ beads as they were seen in all samples. of serum anti-goblet cell antibody, using the cell line as antigen, because an ELISA would be more rapid and less expensive to perform. There had been no simple and rapid assay for anti-colon antibody in ulcerative colitis until ELISA was established by Das et al and ourselves. ${ }^{320}$ To prevent the non-specific binding of the serum IgG to the antigen through a IgG Fc binding site in the cell line, ${ }^{21}$ we blocked the IgG Fc binding site by goat IgG in ELISA. These procedures permitted us to detect antibody against the antigen in intestinal goblet cells with certainty and to examine the corresponding antigen carefully.

Western blot analysis failed to show the antigen recognised by circulating anti-goblet cell antibody (data not shown). Therefore, we applied an immunoprecipitation method for the detection of the antigen, and found that the antigen recognised by anti-goblet cell antibody is a $>200 \mathrm{kD}$ glycoprotein. Although many studies have been performed to examine circulating autoantibodies in inflammatory bowel disease, there are few studies tracing the colon specific antigens detected by these autoantibodies. ${ }^{1222}$ Das $e t a l^{12}$ proposed the $40 \mathrm{kD}$ specific antigen detected by the serum and colonic tissue bound antibodies. Their antibodies were reported to react with basolateral membrane of colonic epithelial cells. ${ }^{9}$ But, some monoclonal antibodies established from the $40 \mathrm{kD}$ specific antigen, reacted with gastrointestinal goblet cells. ${ }^{13}$ In this study, this $40 \mathrm{kD}$ antigen was not shown although the antibody against goblet cells were clearly present in the serum samples. The reason for this discrepancy could be explained by the fact that $40 \mathrm{kD}$ antigen is not expressed on HT29-18- $\mathrm{N}_{2}$ cell line (personal communication, T S Halstensen, Norway). Therefore, the antibodies against the $40 \mathrm{kD}$ antigen were not detected in our ELISA and the antibody in this study was different from the antibodies proposed by Das group.

The significance of this antibody is still unclear. Anti-goblet cell antibody could be either a pathogenetic factor responsible for colonic inflammation or a non-pathogenetic epiphenomenon. It seems unlikely that the antibody is a result of a secondary production caused by colonic inflammation, because the patients with diverticulitis and with other colitis by bacterial or amoebic infection did not have this antibody. It may reflect the underlying immunological abnormalities of the antibody positive patients with ulcerative colitis and Crohn's disease. Our newly established ELISA may make it easier to classify anti-goblet cell antibody positive patients into one group in which colonic inflammation may be induced predominantly by immunological abnormalities.

There are several reports that anti-neutrophil antibodies including ANCA are often found in ulcerative colitis and Crohn's disease. ${ }^{15}{ }^{19}$ It is suggested that they are important disease markers ${ }^{23}$ and seem to relate to genetic susceptibility. ${ }^{24}$ To examine the relation between ANCA and anti-goblet cell antibody, we measured ANCA in patients whose serum samples were tested for anti-goblet cell antibody according to the method as described previously.$^{19}$ In contrast with the previous studies in USA and Europe, ANCA were not prevalent in Japanese patients and its frequencies were similar to those of antigoblet cell antibody. We examined the relation between these two kinds of autoantibodies by comparing the optical densities in ELISA. No significant correlation was obtained, supporting the hypothesis that these antibodies do not bind to the similar antigens. The absorption study confirmed this concept. The fact that the association of these two antibodies was present in ulcerative colitis, however, suggests that they seem to be produced in a group of patients who have autoimmunity. These two antibodies in combination might be good disease markers for these patients. Furthermore, we examined the relation between the antibody and HLA-DR2 that was commonly found in patients with ulcerative colitis. ${ }^{25}{ }^{26}$ It seems improbable that anti-goblet cell antibody is a potential marker of genetic susceptibility because there was no association of HLA-DR2 with the antibody.

In conclusion, the antibody detected by our newly established ELISA must be a serological marker for a group of colitis patients who share the same pathological conditions even if this antibody could be an epiphenomenon. Although the role of this anti-goblet cell antibody detected in our newly established method remains unclear, the purification of the corresponding antigen may be a useful tool for elucidating the significance of the antibody and the pathogenesis of one group of inflammatory bowel disease that is positive for the antibody.

This work is supported by a grant in aid from the Ministry of Health and Welfare, Japan. The authors thank Dr K Sugimura and $\mathrm{Dr} \mathrm{H}$ Asakura for their work on HLA analysis. Some of these data have been reported in the 7th International Congress of Mucosal Immunology held in Prague in 1992.

1 Broberger O, Perlmann P. Autoantibodies in human ulcerative colitis. F Exp Med 1959; 110: 657-74.

2 Wright R, Truelove SC. Autoimmune reactions in ulcerative colitis. Gut 1966; 7: 32-40.

3 Hibi T, Ohara M, Toda K, Hara A, Ogata H, Iwao Y, et al. In vitro anticolon antibody production by mucosal or peripheral blood lymphocytes from patients with ulcerative colitis. Gut 1990; 31: 1371-6. 
4 Broberger $O$, Perlmann P. In vitro studies of ulcerative colitis. I Reactions of patients' serum with human fetal colon cell tissue culture colon cells. $\mathcal{F}$ Exp Med 1963; 117 : 705-15.

5 Langercrantz R, Hammarstrom S, Perlmann P, Gustafsson BE. Immunological studies in ulcerative colitis. Clin Exp Immunol 1966; 1: 263-76.

6 Marcussen H, Nerup J. Fluorescent anti-colon and organspecific antibodies in ulcerative colitis. Scand $\mathcal{F}$ Gastroenterol 1973; 8: 9-15

7 Marcussen $\mathrm{H}$. Fluorescent anti-colonic and $\mathrm{E}$ coli antibodies in ulcerative colitis. Scand f Gastroenterol 1978; 14: 277-81 8 Chapman RW, Cottone M, Selby WS, Shepherd HA,
Sherlock S, Jewell DP. Serum autoantibodies, ulcerative colitis and primary sclerosing cholangitis. Gut 1986; 27 86-91.

9 Das KM, Dubin R, Nagai T. Isolation and characterization of colonic tissue-bound antibodies from patients with idiopathic ulcerative colitis. Proc Natl Acad Sci USA 1978; 75 : 4528-32.

10 Hibi T, Aiso S, Yoshida T, Watanabe M, Asakura H, Tsuru S, et al. Anti-colon antibody and lymphocytophilic antibody in ulcerative colitis Clin Exp Immunol 1982; 49: 75-80.

11 Hibi T, Aiso S, Ishikawa $M$, Watanabe $M$, Yoshida $T$, Kobayashi $\mathrm{K}$, et al. Circulating antibodies to the surface antigens on colon epithelial cells in ulcerative colitis. Clin Exp Immunol 1983; 54: 163-8.

12 Takahashi F, Das KM. Isolation and characterization of a colonic autoantigen specifically recognized by colon tissuebound Immunoglobulin $\mathrm{G}$ from idiopathic ulcerative colitis. f Clin Invest 1985; 76: 311-8.

13 Vecchi M, Sakamaki S, Diamond B, Novikoff AB, Das KM. Development of a monoclonal antibody specifically reactive to gastrointestinal

14 Das KM, Sakamaki S, Vecchi M, Diamond B. The production and characterization of monoclonal antibodies to a human colonic antigen associated with ulcerative colitis; cellular localization of the antigen by using monoclonal antibody. localization of the antigen by

15 Saxon A, Shanahan F, Landers C, Ganz T, Targan S. A distinct subset of antineutrophil cytoplasmic antibodies is associated with inflammatory bowel disease. $f$ Allergy Clin Immunol 1990; 86: 202-10.
16 Huet C, Sahuquillo-Merino, Coudrier E, Daniel Louvard. Absorptive and mucus-secreting subclones isolated from a multipotent intestinal cell line (HT-29) provide new models for cell polarity and terminal differentiation. $\mathcal{f}$ Cell Biol for cell polarity and

17 Asakura H, Hibi T, Tanaka T, Miura S, Aiso S, Muraoka M, et al. Reevaluation of selective intraareterial prednisolone injection therapy in ulcerative colitis. $\mathcal{F p n ~} \mathcal{F}$ Gastroenterol $1978 \cdot 75 \cdot 818-25$.

18 Nakane PK, Kawai A. A peroxidase-labeled antibody. A new method of conjugation. $\mathcal{f}$ Histochem Cytochem 1974; 22: 1084-91.

19 Duerr RH, Targan SR, Landers CJ, Sutherland LR, Shanahan F. Anti-neutrophil cytoplasmic antibodies in ulcerative colitis. Comparison with other colitides/diarrheal illness. Gastroenterology 1991; 100: 1590-6.

20 Takahashi F, Shah H, Wise L, Das KM. Circulating antibodies against human colonic extract enriched with a $40 \mathrm{kDa}$ protein in patients with ulcerative colitis. Gut 1990; 31: 1016-20.

21 Kobayashi K, Blaser MJ, Brown WR. Identification of a unique IgG Fc binding site in human intestinal epithelium. unique IgG Fc binding site in hur

22 Roche JK, Fiocchi C, Youngman K. Sensitization to epithelial antigens in chronic mucosal inflammatory disease. Characterization of human intestinal mucosa-derived mononuclear cells reactive with purified epithelial cell-associatd components in vitro. $\mathcal{F}$ Clin Invest 1985; 75: 522-30.

23 Cambridge G, Rampton DS, Stevens TRJ, McCarthy DA, Kamm M, Leaker B. Anti-neutrophil antibodies in inflammatory bowel disease: prevalence and diagnostic role. Gut 1992; 33: 668-74.

24 Shanahan F, Duerr RH, Rotter JI, Yang H, Sutherland LR, McElree $\mathrm{C}$, et al. Neutrophil antibodies in ulcerative colitis: familial agregation and genetic heterogeneity. Gastroenterology 1992; 103: 456-61.

25 Asakura H, Tsuchiya M, Aiso S, Watanabe M, Kobayashi K, Hibi T, et al. Association of human lymphocyte-DR2 antigen with Japanese ulcerative colitis. Gastroenterology antigen with Japan

26 Toyoda H, Wang S-J, Yang H-Y, Redford A, Magalong D, Tyan D, et al. Distinct association of HLA class II genes with inflammatory bowel disease. Gastroenterology 1993; 104: 741-8. 